\title{
GYRFALCON DIET: SPATIAL AND TEMPORAL VARIATION
}

\author{
Eugene Potapov \\ Bryn Athyn College, Bryn Athyn, PA 19009, USA. \\ E-mail: eugenepotapov@gmail.com
}

\begin{abstract}
The diet of the Gyrfalcon (Falco rusticolus) has been studied throughout the range (Potapov and Sale 2005). The species tends to be stenophagous in the majority of the range, especially at the beginning of the breeding season. At this time, the diet is limited to the organisms which live on the snow surface, such as ptarmigan and hare. Most important for Gyrfalcons are two sympatric species of grouse, namely Willow Ptarmigan (Lagopus lagopus) and Rock Ptarmigan (L. muta). Although the ranges of these two grouse species mostly coincide, in some areas only one species is present; e.g., only Rock Ptarmigan in Iceland, and only Willow Ptarmigan in large areas of the flat tundra of Russia. In the areas where both species are present, the Gyrfalcon tends to prefer Willow Ptarmigan. The timing of Gyrfalcon breeding in continental, non-coastal tundra is linked to the beginning of the grouse display. The timing of breeding in the coastal areas is linked to the arrival of waterfowl or seabirds, and varies from site to site. Seasonal changes in the ecosystem, such as snow melt, arrival of migratory birds, ground squirrel arousal from hibernation, and ice breakup on rivers and lakes, make more food available to the falcons, and their diet diversifies. The Gyrfalcon is known to breed in the areas of the Arctic with cyclical abundance of mammals such as lemmings, ground squirrels, and hares. In such areas, hares dominate the diet at the early stages of breeding since the others remain under the snow and are unavailable to the falcons. After Gyrfalcon chicks hatch, there is a variety of birds available for them as food, such as waterfowl, passerines and waders. All play some part in the diet, the composition of which reflects habitat surrounding the nest site. Received 31 May 2011, accepted 6 June 2011.
\end{abstract}

Potapov, E. 2011. Gyrfalcon diet: Spatial and temporal variation. Pages 55-64 in R. T. Watson, T. J. Cade, M. Fuller, G. Hunt, and E. Potapov (Eds.). Gyrfalcons and Ptarmigan in a Changing World, Volume I. The Peregrine Fund, Boise, Idaho, USA. http://dx.doi.org/10.4080/gpcw.2011.0106

Key words: Gyrfalcon, Falco rusticolus, diet, prey, availability, season.

THE GENERAL RULES OF ECOLOGY propose that a predator which is dependent on just a single species as a food source is vulnerable to local extirpation or even extinction. Conversely, diversity of prey enhances stability of the predator. In this paper, I describe the diet of the Gyrfalcon and its variation in space and time, and speculate that the lack of prey diversity leaves the Gyrfalcon vulnerable to population instability, especially if climate change reduces the availability of its primary prey, ptarmigan.

This paper is a general review of the literature data on the Gyrfalcon diet with some addition of personal experience with the species in North-East Siberia. Since we summarized the papers on the Gyrfalcon's diet (Potapov and Sale 2005), there have been a few new studies 
published (Nystrom et al. 2006, Ganusevich 2006, Gilyazov 2006, Labutin 2006) which are also incorporated into this review. Here we analyze available published data by calculating Shannon's diversity index

$$
\left(H^{\prime}=-\sum_{i=1}^{s} p_{i}^{*} \ln p_{i}\right)
$$

in the diets of Gyrfalcon. Theil's index $\left(\mathrm{T}^{\prime}=\ln \left(\mathrm{N}_{\text {species }}\right)-\mathrm{H}^{\prime}\right.$ or the maximum possible diversity $(\log (\mathrm{N}))$ minus Shannon's diversity index (Theil 1979) is used as a measure of the lack of diversity. Theil's index is increasingly used in economics (Haughton and Khandker 2009) to interpret the inequality in distribution of various parameters (e.g., wealth, shares, resources, population). In biological studies, it measures the distance between the observed distribution of the species of prey in a diet and a theoretical uniform distribution of the prey species. Samples of less than 50 items were excluded from the analysis.

Studies of the Gyrfalcon's diet were traditionally performed at the end of the breeding season, or at the late stage of breeding, when large chicks were present in the nests. Frequent visits to nests were often impossible due to the vulnerability of the species, difficulty of reaching nesting areas, and short duration of the field season. During the early stages of nesting, especially at first breeding displays and egg laying, researchers did not approach the nests to avoid disturbance. These constraints resulted in skewed diet data which mostly represented only the 'developed brood' stage.

\section{Diet Variability Across THE GYRFALCON'S RANGE}

Several studies of the Gyrfalcon's diet were carried out in various localities. The majority of them were done during the breeding period (Table 1). The overall diet of the Gyrfalcon is summarized in Figure 1. The Lagopus grouse dominated the diet in the majority of localities. There were, however, some notable exceptions. In some places, such as Arctic Canada and Greenland (Muir and Bird 1984, Booms and Fuller 2003a,b), a large portion of the diet consisted of the Arctic Hare (Lepus arcticus). The Gyrfalcons brought to the nests only young hares, which were delivered in parts. In Eurasia, the Mountain Hare (L. timidus) was mentioned in the diet of Gyrfalcons in Scandinavia, Komi, Yamal and Yakutia (Huhtala et al. 1996, Hagen 1952, Kalyakin 1989, Kalyakin and Vinogradov 1981, Kishinskiy 1958, Koskimies and Sulkava 2002, Langvatn and Moksnes 1979, Labutin 2006, Mikkola and Sulkava 1972, Pulliainen 1975, Shklyarevich and Krasnov 1980, Voronin 1987). The overall role of this species in the diet of Eurasian Gyrfalcons was, however, much lower than that in North America, and rarely exceeded $4 \%$.

In some regions, Gyrfalcons took various ducks, waders and passerine birds, as well as small mammals. Lemmings and ground squirrels in particular were mentioned in some studies in Arctic Canada (Muir and Bird 1984), Kola (Kishinskiy 1958), Alaska (Cade 1960) and Karyakia (Kishinskiy 1980).

The overall diversity index of prey in the diet of the Gyrfalcon varied from 0.42 to 2.36, average $1.31 \pm 0.569(\mathrm{SD}), \mathrm{N}=28$ (Table 1).

The Theil index (lack of diversity index) in the diet of Gyrfalcon ( $\mathrm{T}^{\prime}$ ) varied from 0.10 to 2.98, average $1.231 \pm 0.628, \mathrm{~N}=28$.

\section{InCUbation Period}

There were only two studies of the Gyrfalcon's diet in the early stage of the breeding season (the incubation period between egg laying and hatching) in Iceland (Nielsen and Cade 1990) and Komi, Russia (Voronin 1983). As an early season breeder, the Gyrfalcon relied on a very limited number of available prey species. In most of its range the most important prey species was either Willow or Rock Ptarmigan. The breeding range of the Gyrfalcon partially coincides with the range of the hare: Arctic Hare in the Canadian High Arctic and Green- 


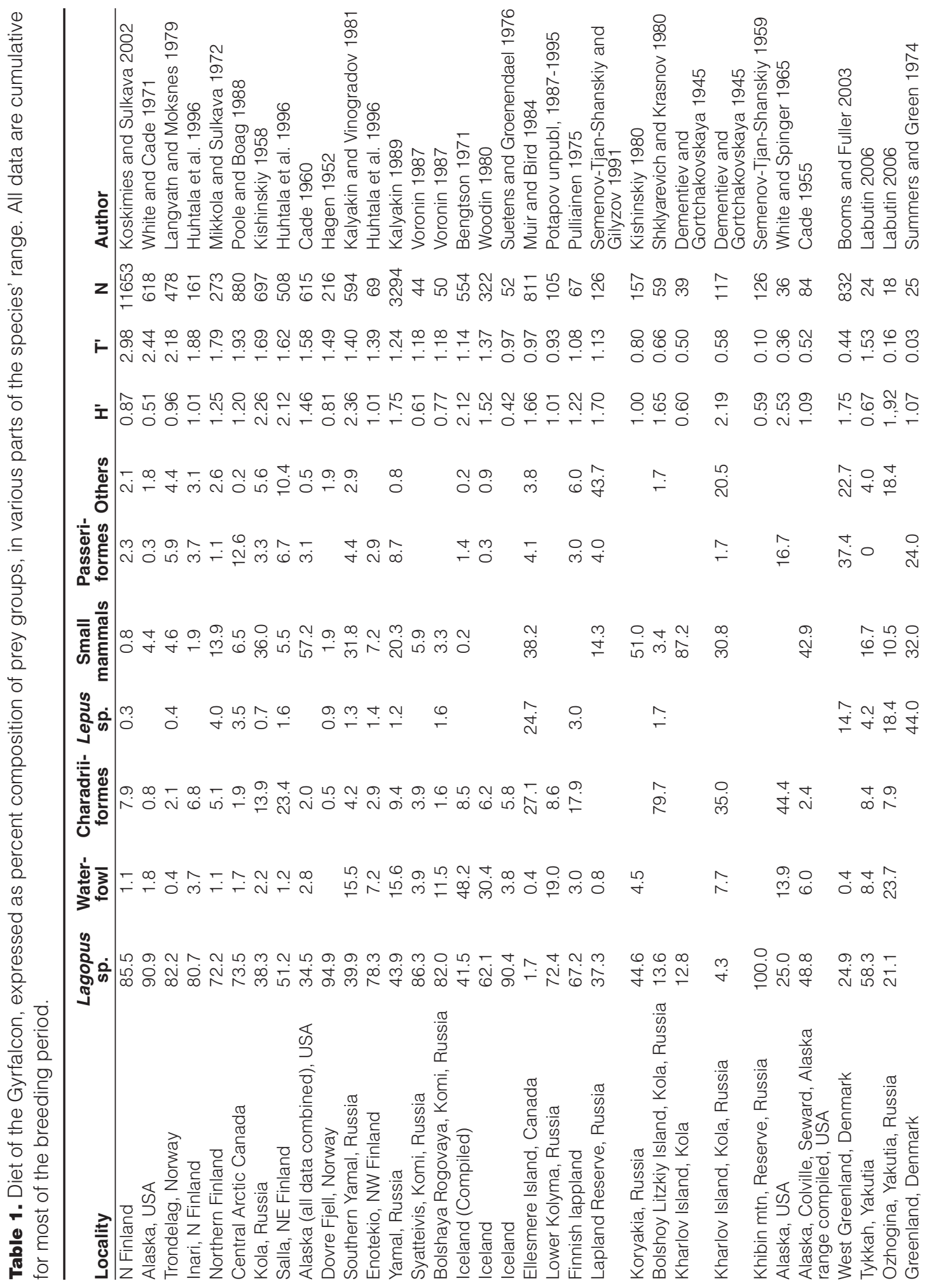


Figure 1. Overall diet composition of the Gyrfalcon during the breeding period. Updated figures from Potapov and Sale 2005 with additions.

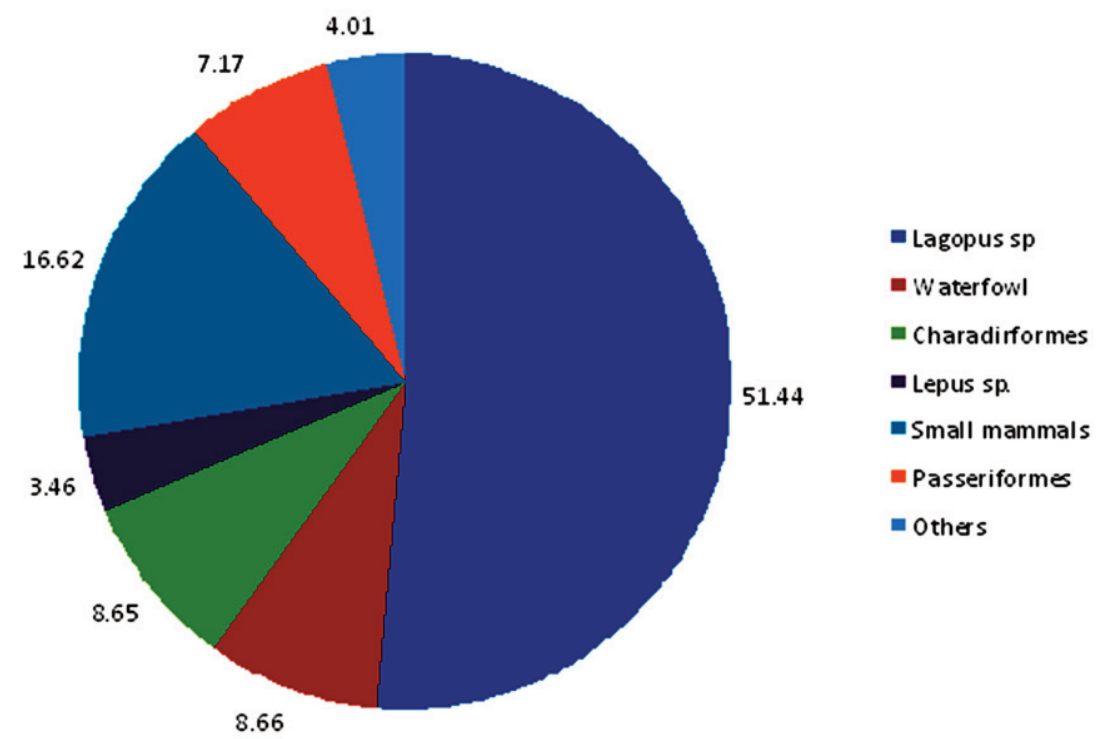

land, and Mountain Hare in Eurasia. In some areas this species also was the only quarry available for Gyrfalcons.

\section{Nestling Period}

The majority of the diet studies of Gyrfalcon covered the nestling period of the breeding cycle when chicks were in the nest. Most of the studies used analysis of prey remains and pellets accumulated at the nests; some authors, however, supplemented this kind of data with direct observations. Voronin (1987) observed a Gyrfalcon nest from 13 June to 12 July 1982 from a hide. He reported that the Gyrfalcons brought two ptarmigan per day. Nevertheless, apart from the Willow Ptarmigan, which clearly dominated in the diet $(86.2 \%)$, he reported that the diet contained Long-tailed Duck Clangula hyemalis (3.9\%), Ruff Philomachus pugnax (2\%), Wood Sandpiper Tringa glareola (3\%), Water Vole Arvicola amphibius (3.9\%), and Muskrat Ondatra zibethicus (2\%). During this stage of the Gyrfalcon's breeding cycle, the snow melts, ptarmigan stop displaying and start to lay eggs, and the summer migrants arrive en-mass. As a result, the num- ber of prey species available to Gyrfalcons increase considerably (Figures 2 and 3 ). The Lagopus species dominated in the diet in the majority of the studies (Table 1), but the local diversity of prey in various regions varied significantly. In some areas, like Yamal Peninsula, Russia, North Finland, or Myvatn Lake, Iceland, ducks played an important role (Bengtson 1971, Kalyakin and Vinogradov 1981, Kalyakin 1989). In other localities, like Kola (Russia) or Salla (Finland), the waders were very important (Huhtala et al. 1996, Kishinskiy 1958). Close to the fledging period, a new shift in the diet occurred: the young of the passerines start fledging, and being an easy target, they immediately appeared in the diet of the Gyrfalcons.

\section{Post-Fledging Dependence Period}

After leaving the nests, the chicks tend to stay together, while the parents still deliver food to them (Potapov and Sale 2005, Kalyakin 1981). A study in Iceland (Nielsen and Cade 1990) registered a sharp increase in the number of the waders and waterfowl in the diet in this period of the breeding cycle. 


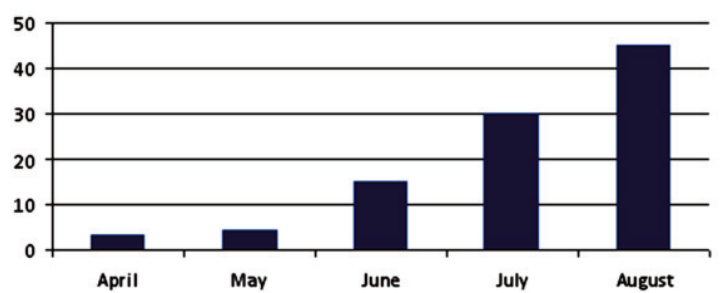

Figure 2. Number of species in the diet of Gyrfalcons from the Lower Kolyma, Russia.

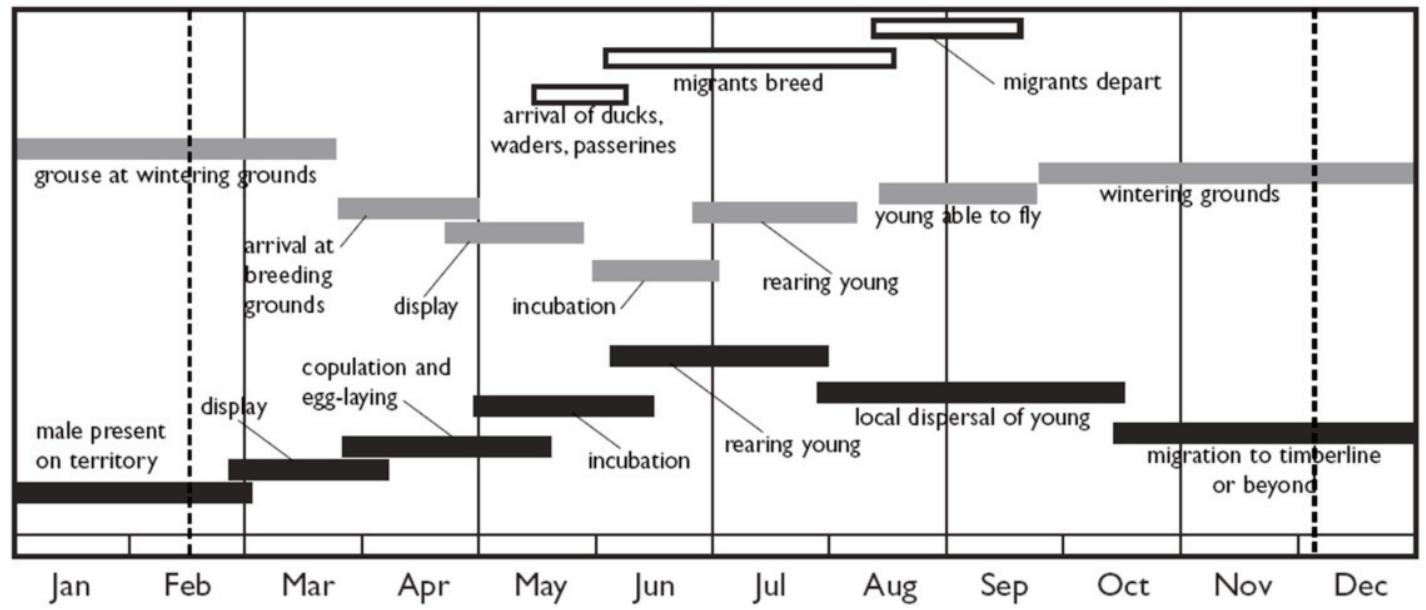

Figure 3. Breeding cycle of the Gyrfalcon (black lines, bottom), Lagopus grouse (grey lines, middle) and Arctic migrants (white lines, top). The polar night lines marked on the chart are equivalent to a latitude of around $70^{\circ} \mathrm{N}$.

\section{WINTER}

Kokhanov (1970) studied the winter diet of Gyrfalcons in the Kola, Russia, a locality within the species' breeding range. He mentioned that the most important prey of Gyrfalcons were bird species common in a seabird colony where the Gyrfalcons were wintering: Thin-billed Murre Uria aalge, Common Somateria mollissima and King S. spectabilis Eiders, Atlantic Puffin Fratercula arctica, and Northern Fulmar Fulmarus glacialis. In Iceland, ptarmigan played an important role, with some addition of waders in the coastal areas (Nielsen and Cade 1990). While wintering outside the breeding range, Gyrfalcons fed on medium- and large-sized birds, such as pigeons and partridges (Potapov and Sale 2005), Sage Grouse Centrocercus urophasianus (Garber et al. 1993), ducks (Dekker and Court 2003), and occasionally carrion and poultry (Tømmeraas 1988, 1989).

\section{Discussion}

The average prey species diversity in the diet of Gyrfalcon (H') was 1.31, which is lower compared to generalist predators. For example Eagle Owl (Bubo bubo) diet had a Shannon diversity index of 1.935-2.325 (Penteriani et al. 2005). The average Theil index (1.28) was comparable to the Shannon index. This means that the diet is skewed towards minimal number of species and the Gyrfalcon tends to be a specialized predator. It is stenophagous at the early stages of the breeding cycle as only few prey species are available at the breeding 
ground at this time. These are mostly Willow and Rock Ptarmigan, followed in some localities by the Arctic Hare.

There is a marked difference in the utilization of hare by Gyrfalcons of the New and Old World. The latter consumed many fewer hares than the North American and Greenland Gyrfalcons. The use of Arctic Hare by Gyrfalcons of the New World was not uniform across the range. In some places, the proportion of hare in the diet was comparable to that of ptarmigan (Booms and Fuller 2003a,b), but in other cases, hares and other mammals dominated the diet (Muir and Bird 1984). These differences are evidently caused by the distribution of the Arctic Hare and its habitat preferences. The range of this species, which prefers to live in open areas without any shrub vegetation (Hoffman and Smith 2005), coincides with the Gyrfalcon's breeding range only in Arctic Canada and Greenland. The abundance of hare changes from year to year, and in some years, its local density is high enough to support Gyrfalcons . The question remains how Gyrfalcons manage to kill and deliver to their nests such a large prey item. Booms and Fuller (2003a) demonstrated that, in Greenland, Gyrfalcons delivered to the nests only small hares, and most frequently only part of them. In all other places, the hare overlaps with the Gyrfalcon's breeding range only in shrubby tundra and forest-tundra, where its availability is somewhat limited.

The majority of studies of the Gyrfalcon's diet were cumulative, i.e., the pellets and prey remains were picked up after the chicks had left the nest, or were close to fledging. This suggests that the feathers and other remains of small prey items could be blown away and therefore underrepresented in the total count. Small passerines seem to be underrepresented in the diet mostly for this reason. It is only possible to eliminate such bias by visiting the nest frequently (but at the risk of disturbing the birds) or to set up an automated imaging system. Such a system was deployed in the diet study in Greenland (Booms and Fuller 2003c) and proved to be unbiased. A detailed study in Iceland (Nielsen and Cade 1990) provided enough resolution by a relatively high frequency of nest visits and records of kills, as well as by a large enough sample size.

It appears that the overall specialization of the Gyfalcons on ptarmigan is evident from March to early June, when the falcons are strictly stenophagous (see the timeline in Figure 3). At this stage, Gyrfalcons consumed the same proportion of ptarmigan males and females. Both sexes at this time are predominantly white and snow cover is present. In May, Willow Ptarmigan males get their reddish neck coloration, while the male Rock Ptarmigan get their black stripe connecting their eye and beak. There was no marked difference in the abundance of male and female ptarmigan in the Gyrfalcon's diet at this stage either. In June, female ptarmigan molt into summer plumage and keep a low profile while incubating. The males still continue to display from time to time, and tend to be visible. At this stage the overall importance of ptarmigan in the Gyrfalcon's diet declines, as was clearly demonstrated by the study in Iceland (Nielsen and Cade 1990); however, the Gyrfalcons' predation pressure on male ptarmigan increases proportionally, as was shown in Komi Republic (Voronin 1983) and Canada's North West Territories (Cotter et al. 1992). The proportion of other species, such as waders, ducks, and passerines in this period, increases in the diet.

Nielsen (1999) found that in the spring, species diversity in the diet of Gyrfalcons in Iceland showed a statistically significant decline when ptarmigan population density increased. This means that if ptarmigan numbers are high, there is no need for Gyrfalcons to spend time and effort hunting other species. In years of low ptarmigan density, the diet becomes more diverse as the Gyrfalcons switch to other species, mostly waders and ducks. This is especially visible in the diverse coastal habitats (Nielsen and Cade 1990). In contrast, Huhtala and co-authors (1996) found no correlation 
between the abundance of the main prey of Gyrfalcons in Northern Finland (Willow Ptarmigan) and the species diversity in the Gyrfalcon's diet. I found no statistically significant correlation between the percentage of ptarmigan in the diet and Shannon index given in the Table 1. This suggests that in the cumulative studies of Gyrfalcon diet, the stenophagy is hidden by a wide variety of prey species added during the late nesting period.

\section{Literature Cited}

Bengtson, S.-A. 1971. Hunting methods and choice of prey of Gyrfalcons Falco rusticolus at Myvatn in northeast Iceland. Ibis 113:468-476.

BoOMs, T. L., AND M. R. FulleR. 2003a. Gyrfalcon feeding behavior during the nestling period in central West Greenland. Arctic 56(4):341-348.

Booms, T. L., AND M. R. FULLER. 2003b. Gyrfalcon diet in central west Greenland during the nesting period. Condor 105:528-537.

BoOms, T. L., AND M. R. FULLER. 2003c. Timelapse video system used to study nesting Gyrfalcons. Journal of Field Ornithology 74(4):416-422.

CADE, T. 1955. The predatory habits of Peregrines and Gyrfalcons in Alaska. Falconry News and Notes: The Journal of Falconry Club of America 1(6):5-20.

CAdE, T. 1960. Ecology of the Peregrine and Gyrfalcon populations in Alaska. University of California Publications in Zoology 63:151-290.

Cotter, R. C., D. A. Boag, And C. C. Shank. 1992. Raptor predation on Rock Ptarmigan (Lagopus mutus) in the central Canadian Arctic. Journal of Raptor Research 26(3):146-151.

DekKer, D., And G. Court. 2003. Gyrfalcon predation on Mallards and the interaction of Bald Eagles wintering in central Alberta. Journal of Raptor Research 37(2):161-163.
Dementiev, G. P., AND N. N. GoRTCHAKOVSKAYA. 1945. On the biology of the Norwegian Gyrfalcon. Ibis 87:559-565.

GANUSEVICH, S. 2006. Status and monitoring of the Peregrine and Gyrfalcon in the Kola Peninsula, Russia. Pages 30-36 in P. Koskimies and N. V. Lapshin (Eds.). Status of Raptor Populations in Eastern Fennoscandia. Proceedings of the Workshop, Kostomuksha, Karelia, Russia, November 8-10, 2005.

Garber, C. S., B. D. Mutch, and S. Platt. 1993. Observations of wintering Gyrfalcons (Falco rusticolus) hunting Sage Grouse (Centrocercus urophasianus) in Wyoming and Montana USA. Journal of Raptor Research 27(3):169-171.

GilyaZOV, A. 2006. Population of diurnal raptors (Falconiformes) in the Lapland Nature Reserve and adjacent areas: Dynamics in 1930-2005. Pages 35-43 in P. Koskimies and N.V. Lapshin (Eds.). Status of Raptor Populations in Eastern Fennoscandia. Proceedings of the Workshop, Kostomuksha, Karelia, Russia, November 8-10, 2005.

Hagen, Y. 1952. The Gyr-falcon (Falco r. rusticolus L.) in Dovre, Norway. Some breeding records and food studies. Skrifter Utgitt av det Norske Vidensaps-Akademi I Oslo. 1. Matematisk-Naturvidenskapelige Klasse 4:5-37.

HaUghton, J., AND S. KhandKer. 2009. Handbook on Poverty and Inequality. World Bank, Washington, DC, USA. http://go. worldbank.org/4WJH9JQ350 (Accessed 11 March 2011)

HofFMAn, R. S., AND A. T. SMIth. 2005. Order Lagomorpha. Pages 185-211 in D. E. Wilson, and D. M. Reeder (Eds.). Mammal Species of the World: A Taxonomic and Geographic Reference, $3^{\text {rd }}$ ed. Johns Hopkins University Press, Baltimore, Maryland, USA.

Huhtala, K., E. Pulliainen, P. Jussila, and P. S. TUNKKARI. 1996. Food niche of the Gyrfalcon Falco rusticolus nesting in the far north of Finland as compared with other 
choices of the species. Ornis Fennica 73:78-87.

KALYAKIN V. N., AND V. G. VinOGRAdOV. 1981. [On breeding of Gyrfalcons in the south of the Yamal Peninsula]. Bulletin of the Moscow Society of Naturalists, Department of Biology 86(5):42-51 (in Russian).

KALYAKIN, V. N. 1989. Birds of prey in extreme North ecosystems. Pages 51-112 in Yu. I. Chernov (Ed.). Birds in the Natural Communities of the Tundra Zone. Nauka, Moscow, Russia (in Russian).

KISHINSKIY, A. A. 1958. [The biology of the Gyrfalcon Falco gyrfalco gyrfalco in the Kola Peninsula]. Uchenye zapiski MGU [Scientific Notes of Moscow State University, 197]. Ornitologia 1:61-75 (in Russian).

KISHINSKIY A. A. 1980. [Birds of Koryak Mountains]. Nauka Publishers, Moscow, Russia (in Russian).

KoKHANOV, V. D. 1970. [On winter diet of the Gyrfalcon]. Proc. of the Kandalaksha Nature Reserve, Murmansk 8:233-235 (in Russian).

Koskimies, P., AND S. Sulkava. 2002. Tunturihaukka elää riekolla ja kiirunalla. Linnut 37(4):6-10.

Labutin, Yu. V., and D. H. Ellis. 2006. Gyrfalcon (Falco rusticolus) in Yakutia: Distribution, nesting regions and features of diet. Zoological Journal 85(11):1354-1361 (in Russian).

Langvatn, R., AND A. Moksnes. 1979. On the breeding ecology of the Gyrfalcon Falco rusticolus in Central Norway. Fauna Norvegica Series C, Cinclus 2:27-39.

Mikkola, H., AND S. SulkaVA. 1972. Mitä syö tunturihaukka [What do Gyrfalcons eat?]. Suomen Luonto 5:183-185 (in Finnish).

MuIR, D., AND D. M. BIRD. 1984. Food of Gyrfalcons at a nest on Ellesmere Island. Wilson Bulletin 96(3):464-467.

Nielsen, Ó. K., AND T. J. CADE. 1990. Seasonal changes in food habits of Gyrfalcons in NE-Iceland. Ornis Scandinavica 21:202211.
Nielsen, Ó. K. 1999. Gyrfalcon predation on ptarmigan: Numerical and functional responses. Journal of Animal Ecology 68:1034-1050.

Nyström J., L. Dalén, P. Hellström, J. Ekenstedt, H. ANGLEBy, AND A. ANGerbJÖRN. 2006. Effect of local prey availability on Gyrfalcon diet: DNA analysis on ptarmigan remains at nest sites Journal of Zoology 269(1):57-64.

Penteriani, V., F. Sergio, M. M. Delgado, M. Gallardo, AND M. Ferrer. 2005. Biases in population diet studies due to sampling in Heterogeneous environments: A case study with the Eagle Owl. Journal of Field Ornithology 76(3):237-244.

Poole, K. G., AND D. A. BoAg. 1988. Ecology of Gyrfalcons, Falco rusticolus, in the Central Canadian Arctic: Diet and feeding behavior. Canadian Journal of Zoology 66:334-344.

Potapov, E., And R. SAle. 2005. The Gyrfalcon. T. \& A. D. Poyser, London, UK and Yale University Press, New Haven, Connecticut, USA.

Pulliainen, E. 1975. Choice of prey by a pair of Gyrfalcons (Falco rusticolus) during nesting period in forest-Lapland. Ornis Fennica 52:19-22.

SEMENOV-TYAN-SHANSKIY, O. I. 1959. Ecology of Tetraonidae Birds. Lapland State Reserve, Moscow, Russia.

SEmenov-Tyan-Shanskiy, O. I., AND A. S. Gilyazov. 1991. Birds of Lappland. Nauka Publishers, Moscow, Russia.

ShKlyarevich, F., AND Yu. Krasnov. 1980. The biology of the Lappland Gyrfalcon (Falco gyrfalco gyrfalco L.) in the Kola Peninsula. Pages 17-26 in V. A. Zabrodin (Ed.). Ecology of the Birds of the Sea Coasts. TSNIL Glavokhota, Moscow, Russia (in Russian).

Summers, R. W., AND G. H. Green. 1974. Notes on the food of the Gyrfalcon Falco rusticolus in North-East Greenland in 1972. Dansk Ornithologisk Forenings Tidsskrift 68:87-90. 
Suetens, W., and P. Van Groenendael. 1976. Observations au nid du Faucon Gerfaut (Falco rusticolus) en Islande. Le Gerfaut 66:44-61.

THEIL, H. 1979. The measurement of inequality by components of income. Economics Letters 2:197-199.

TøMmeraAs, P. 1988. Gyrfalcon Falco rusticolus predation on poultry and domestic animals: A review. Dansk Ornithologisk Forenings Tidsskrift 82:109-116.

TømmeraAs, P. 1989. Carrion feeding in the Gyrfalcon Falco rusticolus: A review. Fauna Norvegica Series C, Cinclus 12:6577.

VORONIN, R. N. 1983. [Influence of Gyrfalcon on the population structure of Willow Grouse in the Bolshezemelskaya tundra]. Structure of the bird population of the European part of the NW USSR. Proceedings of the Komi Branch of the Academy of Sciences, Syktyvkar 62:17-20 (in Russian).

Voronin, R. N. 1987. Biology of Gyrfalcon (Falco gyrfalco L.) in the south-east of the Bolshezemelskaya tundra. Bulletin of the Moscow Society of Naturalists, Department of Biology 92(6):10-17 (in Russian.)

White, C. M., AND T. J. CADE. 1971. Cliffnesting raptors and ravens along Colville River in arctic Alaska. Living Bird 10:107150.

White, C. M., And H. K. Springer. 1965. Notes on the Gyrfalcon in west coastal Alaska. Auk 82(1):104-105.

Woodin, N. 1980. Observations on Gyrfalcons (Falco rusticolus) breeding near Lake Myvatin, Iceland, 1967. Journal of Raptor Research 14(4):97-124. 
- PotAPOV - 